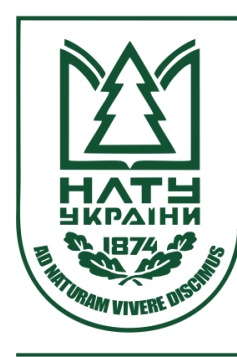

Науковий вісник НЛТУ України Scientific Bulletin of UNFU

https://nv.nltu.edu.ua

https://doi.org/10.36930/40300404

$@ \bowtie$ Correspondence author

Article received $17.09 .2020 \mathrm{p}$.

Article accepted 08.09.2020 p.

O. L. Kratiuk

UDC $630 * 521.1: 631.1(477.42)$

deneshi_ks@ukr.net

О. Л. Кратюк

Житомирський наџіональний агроекологічний університет, м. Житомир, Украйна

\title{
ЗМІНА ДІЕЛЕКТРИЧНИХ ПОКАЗНИКІВ СОСНИ ЗВИЧАЙНОЇ В УМОВАХ НАПІВВІЛЬНОГО УТРИМАННЯ КАБАНА ДИКОГО
}

На прикладі Центрального Полісся України показано особливості використання електрофізіологічних показників (імпедансу $(R)$ і поляризаційної ємності $(C)$ ) є перспективним методом індикації стадій впливу напіввільного утримання мисливських тварин на лісові насадження. На території Центрального Полісся функціонує близько 30 вольєрів, у яких утримують кабана дикого (Sus scrofa L.). Досліджено сезонні зміни діелектричних показників сосни звичайної (Pinus sylvestris L.) на території вольєрів ТОВ "УТМР", ГО "ЖОМК "Касадор", ДП "Баранівське ЛМГ", ДП "Лугинське ЛГ", ДП "Коростишівське ЛГ" та ГО "Романівський МРК "Ірбіс-Брачки", площа яких не перевищує 5,0 га. Закладено 12 пробних площ (шість 3 яких - контрольні) у соснових деревостанах віком 60-91 рік, які зростають за I вані у трьох типах лісу $\left(\mathrm{B}_{2}\right.$-дС, $\mathrm{C}_{2}$-гдС, $\mathrm{C}_{3}$-гдС). Вимірювання діелектричних показників виконували у лютому-березні, червні-липні та жовтні-листопаді упродовж 2018-2020 pр. приладом Ф4320 на частоті 1000 Гц за методикою Г. Т. Криницького. Встановлено, що діелектричні показники мають виражену динаміку та характеризують сезонні зміни інтенсивності процесів життєдіяльності. Поляризаційна ємність на пробних площах коливалася у лютому-березні в межах $5,68^{ \pm 0,17}$ $7,46^{ \pm 0,25} \mathrm{nF}$, у червні-липні вона зросла до $11,31^{ \pm 0,67}-24,55^{ \pm 0,91} \mathrm{nF}$, а у жовтні-листопаді знизилася до $6,03^{ \pm 0,29}-8,97^{ \pm 0,27} \mathrm{nF}$. Показники імпедансу впродовж сезону спочатку знизилися від $22,43^{ \pm 0,63}-36,10^{ \pm 2,48}$ кОм до $10,20^{ \pm 0,54}-21,83^{ \pm 1,35}$ кОм, а потім зросли до $20,50^{ \pm 0,59}-33,35^{ \pm 2,49}$ кОм. Встановлено достовірну різницю діелектричних показників насаджень Pinus sylvestris для вольєрів ДП "Баранівське ЛМГ" $\left(C-t_{\phi}=2,72-3,88\right.$ та $\left.R-t_{\phi}=2,24-3,05 ; t_{05}=2,02\right)$ та ДП "Лугинське ЛГ" $\left(C-t_{\phi}=2,78\right.$ 11,69 та $\left.R-t_{\phi}=2,52-8,93 ; t_{05}=2,02\right)$. Коефіцієнт варіації поляризаційної ємності на дослідних пробних площах за періодами спостереження становив відповідно 14,1-19,4 \%, 16,6-31,5\% та 8,9-21,7 \%, а імпедансу - 12,7-34,7 \%, 15,7-35,2 \% та 12,8$38,4 \%$. У червні-липні (період активної вегетації), на фоні загального зростання показників поляризаційної ємності та зниження імпедансу, відчутно зросли коефіцієнти варіації поляризаційної ємності на ПП $\left(\left(F_{\text {факm }}=47,56>>F_{0,95}(1 ; 21)=4,35\right)\right)$ порівняно з попереднім періодом, водночас для імпедансу таке збільшення коефіцієнта варіації не спостерігається $\left(\left(F_{\text {факm }}=\right.\right.$ $\left.\left.0,24<F_{0,95}(1 ; 21)=4,35\right)\right)$. Отримані результати досліджень свідчать про неоднозначність впливу напіввільного утримання Sus scrofa на життедіяльність дерев Pinus sylvestris.

Ключові слова: поляризаційна ємність; імпеданс; Pinus sylvestris L.; вольєр; Sus scrofa.

\section{Вступ}

Перші спроби оцінити стан тканин рослин за допомогою імпедансу $(R)$ та поляризаційної ємності $(C)$, здійснені у другій половині XX ст., показали позитивні результати $[4,5,6]$. Згодом на основі праць доктора Алекса Л. Шиго (Dr. Alex L. Shigo) розроблено методику визначення стану лісових насаджень за допомогою діелектричних показників. Для цього було створено вимірювальний прилад (згодом названий шигометром shigometer - на честь розробника), який використовував імпульсний електричний струм для визначення імпедансу [29]. Це стало поштовхом до широкого застосування методу шигометрії у лісовому господарстві [27]. Наразі визначення діелектричних показників $\epsilon$ невід'ємною компонентою проведення лісівничо-екологічних і селекційно-генетичних досліджень $[21,30,10]$. Таке широке застосування поляризаційної ємності та імпедансу під час проведення еколого-лісівничих дос- ліджень спонукає до пошуку нових ефективних методів і способів ранньої діагностики стадій мисливсько-господарської дигресії лісових насаджень, особливо в умовах напіввільного утримання мисливських тварин.

Об'єкт дослідження - деревостани сосни звичайної (Pinus sylvestris L.), що зростають у межах вольєрів на території Центрального Полісся.

Предмет дослідження - закономірності впливу напіввільного утримання кабана дикого [Sus scrofa Linnaeus, 1758] на діелектричні показники Pinus sylvestris.

Мета дослідження: становити особливості впливу напіввільного утримання Sus scrofa на діелектричні показники Pinus sylvestris на території вольєрів Центрального Полісся.

Для досягнення зазначеної мети потрібно виконати такі основні завдання дослідження: визначити сезонні зміни діелектричних показників Pinus sylvestris на території вольєрів різної тривалості та інтенсивності експлуатації.

\section{Інформація про автора:}

Кратюк Олександр Леонідович, канд. біол. наук, доцент, завідувач кафедри експлуатації лісових ресурсів. Email: deneshi_ks@ukr.net; https://orcid.org/0000-0002-2661-8074

Цитування за ДСтУ: Кратюк О. Л. Зміна діелектричних показників сосни звичайної в умовах напіввільного утримання кабана дикого. Науковий вісник НЛтУ України. 2020, т. 30, № 4. С. 25-30.

Citation APA: Kratiuk, O. L. (2020). Changing of the dielectric parameters of scots pine in the conditions of semi-free maintenance of wild boar. Scientific Bulletin of UNFU, 30(4), 25-30. https://doi.org/10.36930/40300404 
Наукова новизна отриманих результатів дослідження: вперше для Центрального Полісся проаналізовано сезонні зміни діелектричних показників Pinus sylvestris під впливом напіввільного утримання Sus scrofa на території вольєрів площею до 5,0 га. 3 огляду на стрімке збільшення кількості вольєрів, актуальності набувають питання фізіологічної реакції Pinus sylvestris на умови напіввільного утримання мисливських тварин.

Практична значущість результатів дослідження. За результатами наших досліджень у перспективі можна встановити залежність між площею вольєрів, видовим складом тварин та станом лісових насаджень, що дасть змогу розробити експрес-методи ранньої діагностики стадій мисливсько-господарської дигресії лісових насаджень в умовах вольєрного утримання мисливських тварин. Усе це сприятиме мінімізації негативного впливу напіввільного утримання мисливських тварин на лісові біоценози.

Аналіз останніх досліджень та публікацій. Використовуючи здобутки електрофізіології рослин за останні пів століття вчені розробили цілу низку методик для оцінювання стану лісових насаджень $[20,1,8]$, серед яких особливе місце належить визначенню показників імпедансу та поляризаційної ємності $[16,24]$.

Метод шигометрії з моменту першого свого застосування, у другій половині XX ст., набув широкої популярності завдяки простоті і надійності, проте використання тільки одного показника імпедансу зазвичай ускладнювало інтерпретацію результатів дослідження [28]. Подальший розвиток у цій галузі приводить до створення вдосконаленого методу діагностики стану дерев - електричної резистентної томографії (ERT), який поєднує основні принципи шигометрії та сучасні методи оброблення даних. Томографію електричного опору зазвичай підсилювали за допомогою звукової томографії (SoT) [13], для отримання надійніших результатів. Методи ERT i SoT свого часу мали багато обмежень через дороге обладнання та складність виконання досліджень у польових умовах.

У міру вдосконалення вимірювальної техніки дослідники звернули увагу на показник поляризаційної ємності як електрофізіологічний параметр, який здатен оцінити стан деревних рослин. Було розроблено методику визначення позакореневої біомаси на основі вимірювань поляризаційної ємності та опору стебла [23]. Згодом було запропоновано використовувати поляризаційну ємність для оцінки росту дерев [22].

На початку 1980-их років почали виготовляти портативні вимірювальні прилади (LCR-и (індуктивність, ємність, опір)), які здатні були вимірювати обидва електричні параметри, необхідні в електрофізіології рослин: поляризаційну ємність та імпеданс. В Україні таким приладом став Ф4320, виробництва м. Житомир. Цей LCR-метр працює на частоті 1000 Гц. Вперше на території України його застосував для вимірювання електрофізіологічних показників для визначення життєздатності деревних рослин Г. Т. Криницький [16].

Діелектричні показники, як індикатори впливу чинників навколишнього середовища, застосовують для вивчення різних стадій онтогенезу деревних рослин, а саме: граба звичайного (Carpinus betulus L.) [7], в'яза шорсткого (Ulmus scabra Mill.) [18], дуба звичайного (Quercus robur L.) і бука лісового (Fagus sylvatica L.) [2], лип серцелистої (Tilia cordata Mill.) та широколистої (Tilia platyphyllos Scop.) [11], насаджень за участю модрини європейської (Larix decidua Mill.) [11] тощо. Але все ж найбільший науковий інтерес мають дослідження електрофізіологічних показників Pinus sylvestris $[17,19,25,26,31,32,33]$.

Як показують результати комплексних еколого-фізіологічних досліджень, електрофізіологічні методи визначення життєздатності деревних рослин найбільш інформативні під час ослаблення дерев під дією повільно діючих чинників середовища [9]. До таких чинників можна віднести і вплив напіввільного утримання мисливських тварин. Зокрема, ми встановили особливості впливу напіввільного утримання Sus scrofa на діелектричні показники Pinus sylvestris на території вольєра ДП "Радимишльське ЛМГ" (Центральне Полісся) [13] та у межах вольєрів МСК "Сокіл" (Західне Полісся) [14].

Матеріали та методи дослідження. Вивчення впливу напіввільного утримання Sus scrofa на діелектричні показники Pinus sylvestris здійснювали у вольєрах площею до 5,0 га, користувачами яких є: ТОВ "УТМР", ГО "ЖОМК "Касадор", ДП "Баранівське ЛМГ", ДП "Лугинське ЛГ", ДП "Коростишівське ЛГ" та ГО "Романівський МРК "Ірбіс -Брачки". Характеристику вольєрів подано у табл. 1.

Для досліджень обрали 60-91-річні деревостани $\mathrm{Pi}$ nus sylvestris, що зростають у межах вольєрів. Контролем слугували насадження 3 подібними лісівничо-таксаційними показниками, поза межами вольєрів (табл. 2). За можливості намагалися обирати такі насадження, які під час будівництва вольєра були розділені. Закладено 12 пробних площ (ПП), а саме: шість (ПП №1-ПП №6) на території вольєрів та шість контрольних (ПП №K - -ПП №K 6 ).

У межах кожної ПП відбирали по 20 модельних екземплярів із панівних у фітоценозі дерев. Терміни проведення електрофізіологічних досліджень наведено у табл. 3. Варто зазначити, що дослідження у вольєрі ГО "Романівський МРК "Ірбіс-Брачки" проведено тільки у період активної вегетації у липні 2020 р. під час будівництва.

Табл. 1. Характеристика вольєрів для Sus scrofa

\begin{tabular}{|c|c|c|c|c|c|}
\hline $\begin{array}{c}\text { № } \\
\text { 3/п }\end{array}$ & Користувач & $\begin{array}{c}\text { Рік ство- } \\
\text { рення }\end{array}$ & $\begin{array}{c}\text { Орієнтовна чисельність } \\
\text { поголів'я, особин }\end{array}$ & $\begin{array}{c}\text { Площа вольєра, } \\
\text { га }\end{array}$ & Примітка \\
\hline 1 & ТОВ "УТМР" & 1984 & 15 & $5,0(29,0)^{*}$ & \\
\hline 2 & ГО "ЖОМК "Касадор" & 2002 & 20 & 4,0 & \\
\hline 3 & ДП "Баранівське ЛМГ" & 2012 & 10 & $2,5(56,2)$ & \\
\hline 4 & ДП "Лугинське ЛГ" & 2012 & 11 & 2,3 & \\
\hline 5 & ДП "Коростишівське ЛГ" & 2012 & - & 1,5 & 3 2017 р. не експлуатується \\
\hline 6 & ГО "Романівський МРК "Ірбіс-Брачки" & 2020 & - & 4,2 & \\
\hline
\end{tabular}

Примітка: *у дужках загальна площа вольєра, в межах якого збудовано вольєр для кабана дикого. 
Табл. 2. Лісівничо-таксаційні показники деревостанів на пробних площах

\begin{tabular}{|c|c|c|c|c|c|c|c|}
\hline № ПП & Квартал (виділ) & Склад деревостану & Тип лісу & Вік, років & $\begin{array}{c}\text { Відносна } \\
\text { повнота }\end{array}$ & $\begin{array}{c}\text { Клас } \\
\text { бонітету }\end{array}$ & $\begin{array}{c}\text { Запас, } \\
\text { м/га }^{3}\end{array}$ \\
\hline \multicolumn{8}{|c|}{ ТОВ "УТМР" (Новозаводське л-во, ДП "Житомирське ЛГ") } \\
\hline 1 & $36(23)$ & $10 \mathrm{C} 3+Д 3+В л ч$ & $\mathrm{C}_{3}$-гдС & 90 & 0,70 & $\mathrm{I}^{\mathrm{A}}$ & 440 \\
\hline $\mathrm{K}_{1}$ & $35(30)$ & $10 \mathrm{C}_{3}+Д ч р+Д 3+Г з+Я_{3}$ & $\mathrm{C}_{3}$-гдС & 91 & 0,70 & $\mathrm{I}^{\mathrm{A}}$ & 440 \\
\hline \multicolumn{8}{|c|}{ ГО "ЖОМК "Касадор" (Українське л-во, ДП "Малинське ЛГ") } \\
\hline 2 & $62(34)$ & 6Дз4Ос+Бп+Влч+Сз & $\mathrm{C}_{2}$-гдС & 76 & 0,60 & II & 270 \\
\hline $\mathrm{K}_{2}$ & $62(20)$ & 7ДзЗБп +C3+Oc & $\mathrm{C}_{2}$-гдС & 71 & 0,65 & I & 260 \\
\hline \multicolumn{8}{|c|}{ ДП "Баранівське ЛМГ" (Явненське л-во) } \\
\hline 3 & $19(34)$ & $8 \mathrm{C}_{3} 2$ Бп & $\mathrm{B}_{2}-д \mathrm{C}$ & 91 & 0,92 & $\mathrm{I}$ & 340 \\
\hline $\mathrm{K}_{3}$ & $26(4)$ & 7Сз2Бп1Дз & $\mathrm{B}_{2}-д \mathrm{C}$ & 86 & 0,75 & $\mathrm{I}$ & 360 \\
\hline \multicolumn{8}{|c|}{ ДП "Лугинське ЛГ" (Лугинське л-во) } \\
\hline 4 & $109(30)$ & 4Бп 3Сз1Дз1Яле1Влч & $\mathrm{C}_{2}$-гдС & 80 & 0,50 & II & 190 \\
\hline $\mathrm{K}_{4}$ & $109(25)$ & 6Бп 3Сз1Влч & $\mathrm{C}_{2}$-гдС & 80 & 0,50 & $\mathrm{I}$ & 200 \\
\hline \multicolumn{8}{|c|}{ ДП "Коростишівське ЛГ" (Коростишівське л-во) } \\
\hline 5 & 19(16) & 9Сз1Влч+Бп & $\mathrm{C}_{3}$-гдС & 60 & 0,65 & $\mathrm{I}^{\mathrm{B}}$ & 410 \\
\hline $\mathrm{K}_{5}$ & $19(16)$ & 9Сз1Влч+Бп & $\mathrm{C}_{3}$-гдС & 60 & 0,65 & $\mathrm{I}^{\mathrm{b}}$ & 410 \\
\hline \multicolumn{8}{|c|}{ ГО "Романівський МРК "Ірбіс-Брачки" (Соболівське л-во, ДП "Романівське ЛГ АПК") } \\
\hline 6 & $92(19)$ & $10 \mathrm{C} 3+$ Бп+Oc+Д3 & $\mathrm{C}_{3}$-гдС & 60 & 0,85 & $\mathrm{I}^{\mathrm{A}}$ & 430 \\
\hline $\mathrm{K}_{6}$ & $92(19)$ & $10 \mathrm{C}_{3}+$ БП+Оc+Дз & $\mathrm{C}_{3}$-ГдС & 60 & 0,85 & $\mathrm{I}^{\mathrm{A}}$ & 430 \\
\hline
\end{tabular}

Табл. 3. Терміни визначення діелектричних показників Pinus sylvestris на території вольєрів Центрального Полісся

\begin{tabular}{|c|c|c|c|c|}
\hline \multirow{2}{*}{ № 3/п } & \multirow{3}{*}{ Користувач } & \multicolumn{3}{|c|}{ Терміни проведення досліджень } \\
\cline { 3 - 5 } & & $\begin{array}{c}\text { Період виходу } \\
\text { зі стану спокою }\end{array}$ & $\begin{array}{c}\text { Період активної } \\
\text { вегетації }\end{array}$ & $\begin{array}{c}\text { Період переходу } \\
\text { до стану спокою }\end{array}$ \\
\hline 1 & ТОВ "УТМР" & березень 2019 & липень 2019 & листопад 2019 \\
\hline 2 & ГО "ЖОМК "Касадор" & березень 2020 & липень 2020 & жовтень 2019 \\
\hline 3 & ДП "Баранівське ЛМГ" & лютий 2019 & червень 2019 & жовтень 2019 \\
\hline 4 & ДП "Лугинське ЛГ" & березень 2018 & липень 2018 & жовтень 2018 \\
\hline 5 & ДП "Коростишівське ЛГ" & березень 2019 & липень 2019 & жовтень 2019 \\
\hline 6 & ГО "Романівський МРК "Ірбіс-Брачки" & & липень 2020 & \\
\hline
\end{tabular}

Для визначення інтенсивності процесів життєдіяльності Pinus sylvestris використали діелектричні показники (імпеданс $(R)$ і поляризаційну ємність $(C))$ прикамбіальних тканин лубу на висоті стовбура 1,3 м. Вимірювання виконували аналоговим приладом Ф4320 на частоті 1 кГц за методикою Г. Т. Криницького [16].

\section{Результати дослідження та їх обговорення}

На території Центрального Полісся, за орієнтовними даними, функціонує близько 30 вольєрів, у яких утримують Sus scrofa. Щонайменше 17 з них має площу до 5,0 га. Для дослідження ми обрали вольєри 3 різною тривалістю експлуатації. Найстарішим серед них $є$ вольєр ТОВ "УТМР". Його побудовано у 1984 р. (тоді МГ "В'юнки") для утримання оленя плямистого (Cervus nippon Temminck, 1838), проте від самого створення у вольєрі в окремій загорожі утримували і Sus scrofa. 3 моменту свого створення у 2002 р. і дотепер вольєр ГО "ЖОМК "Касадор" (до 2017 р. належав ДП "Малинське ЛГ") інтенсивно використовували для утримували Sus scrofa. Вольєр на території Явненського лісництва ДП "Баранівське ЛМГ" створено згідно з рішенням технічної ради Баранівського лісгоспзагу від 16.03.1985 р. на площі 56,2 га для розведення Cervus nippon. У 2012 р. частину вольєра площею 2,5 га відгородили для утримання Sus scrofa. У такий спосіб насадження цього вольєра упродовж 26 років були під впливом Cervus nippon, а наступні 8 - під впливом Sus scrofa. Загалом у 2012 р. у межах поліської частини Житомирської області побудовано 7 вольєрів для утримання Sus scrofa. Ceред них були вольєри ДП "Лугинське ЛГ" та ДП "Коростишівське ЛГ", проте експлуатація останнього тривала тільки у період 2012-2017 pp. Наразі будують вольєр ГО "Романівський МРК "Ірбіс-Брачки". Насад- ження Pinus sylvestris у межах цього вольєра можна вважати контрольними. Варто зазначити, що вік соснових деревостанів цього вольєра $є$ ідентичним віку насаджень Pinus sylvestris у вольєрах ТОВ "УТМР", ДП "Баранівське ЛМГ" та ГО "ЖОМК "Касадор" на момент початку експлуатації. Це дасть змогу в майбутньому оцінити ступінь впливу напіввільного утримання Sus scrofa на соснові насадження.

Поляризаційна ємність у період виходу зі стану спокою (лютий-березень) на дослідних ПП №1-ПП №5 коливалася у межах $5,68^{ \pm 0,17}-7,45^{ \pm 0,27} \mathrm{nF}$, водночас на контрольних ПП №К - -ПП №K 5 вона становила $6,53^{ \pm 0,25}$ $7,46^{ \pm 0,25} \mathrm{nF}$ (табл. 4). Коефіцієнт варіації показника незначний як на дослідних $(13,2-16,2 \%)$, так і на контрольних (14,9-19,4 \%) пробних площах. Достовірність різниці між дослідними і контрольними показниками зафіксовано на ПП №3 (ДП "Баранівське ЛМГ") та ПП №4 (ДП "Лугинське ЛГ") (відповідно $t_{\phi}=2,81$ та $t_{\phi}=2,78$ при $\left.t_{05}=2,02\right)$, де показники поляризаційної ємності на контрольних ділянках були вищими на 14,9$15,0 \%$ (табл. 5). Для інших пар ПП не існує достовірної $\left(t_{\phi}=0,03-0,73 ; t_{05}=2,02\right)$ різниці. У лютому-березні імпеданс на ПП №1-ПП №5 змінювався у межах $23,57^{ \pm 1,30}-36,10^{ \pm 2,48}$ кОм, а на ПП №К - -ПП №К новив $22,43^{ \pm 0,63}-29,55^{ \pm 1,54}$ кОм. Коефіцієнт варіації на дослідних ПП становить $18,8-34,7 \%$, а на контрольних - 12,7-30,6 \%. Достовірність різниці показників імпедансу зафіксовано також для ПП №3 (ДП "Баранівське ЛМГ") та ПП №4 (ДП "Лугинське ЛГ") (відповідно $t_{\phi}=2,24$ та $t_{\phi}=2,51$ при $t_{05}=2,02$ ) порівняно 3 контрольними показниками. На інших ПП контрольні показники становлять 95,2-103,8 \% до дослідних $\left(t_{\phi}=0,38-0,80 ; t_{05}=2,02\right)$. 
Табл. 4. Діелектричні показники Pinus sylvestris в умовах напіввільного утримання Sus scrofa

\begin{tabular}{|c|c|c|c|c|c|c|c|c|c|c|c|c|}
\hline \multirow{3}{*}{$\begin{array}{c}\text { № } \\
\text { ПП }\end{array}$} & \multicolumn{2}{|c|}{$C, \mathrm{nF}$} & \multicolumn{2}{|c|}{$R$, кОм } & \multicolumn{2}{|c|}{$C, \mathrm{nF}$} & \multicolumn{2}{|c|}{$R$, кОм } & \multicolumn{2}{|c|}{$C, \mathrm{nF}$} & \multicolumn{2}{|c|}{$R$, кОм } \\
\hline & $M^{ \pm m}$ & $V, \%$ & $M^{ \pm m}$ & $V, \%$ & $M^{ \pm m}$ & $V, \%$ & $M^{ \pm m}$ & $V, \%$ & $M^{ \pm m}$ & $V, \%$ & $M^{ \pm m}$ & $V, \%$ \\
\hline & \multicolumn{4}{|c|}{ Період виходу зі стану спокою } & \multicolumn{4}{|c|}{ Період активної вегетаиії } & \multicolumn{4}{|c|}{ Період переходу до стану спокою } \\
\hline 1 & $6,82^{ \pm 0,22}$ & 14,2 & $30,50^{ \pm 1,28}$ & 18,8 & $17,90^{ \pm 0,82}$ & 20,6 & $10,80^{ \pm 0,77}$ & 31,7 & $6,03^{ \pm 0,29}$ & 21,7 & $33,05^{ \pm 2,39}$ & 32,3 \\
\hline$K_{1}$ & $6,56^{ \pm 0,28}$ & 19,4 & $29,40^{ \pm 2,01}$ & 30,6 & $17,44^{ \pm 1,16}$ & 29,6 & $12,18^{ \pm 0,68}$ & 25,0 & $6,48^{ \pm 0,23}$ & 15,6 & $33,35^{ \pm 2,49}$ & 33,4 \\
\hline 2 & $7,45^{ \pm 0,27}$ & 16,2 & $23,57^{ \pm 1,30}$ & 24,6 & $20,05^{ \pm 1,15}$ & 25,7 & $10,55^{ \pm 0,73}$ & 31,1 & $8,61^{ \pm 0,17}$ & 8,9 & $21,40^{ \pm 0,98}$ & 20,4 \\
\hline$K_{2}$ & $7,46^{ \pm 0,25}$ & 14,9 & $22,43^{ \pm 0,63}$ & 12,7 & $17,90^{ \pm 0,91}$ & 22,8 & $10,20^{ \pm 0,54}$ & 23,6 & $9,23^{ \pm 0,38}$ & 18,3 & $20,45^{ \pm 1,05}$ & 22,9 \\
\hline 3 & $5,68^{ \pm 0,17}$ & 13,2 & $36,10^{ \pm 2,48}$ & 30,8 & $12,15^{ \pm 0,69}$ & 25,2 & $21,83^{ \pm 1,35}$ & 27,8 & $6,93^{ \pm 0,26}$ & 16,9 & $30,20^{ \pm 2,59}$ & 38,4 \\
\hline$K_{3}$ & $6,53^{ \pm 0,25}$ & 17,2 & $29,55^{ \pm 1,54}$ & 23,4 & $15,25^{ \pm 0,91}$ & 26,7 & $16,15^{ \pm 1,27}$ & 35,2 & $8,82^{ \pm 0,41}$ & 21,0 & $22,77^{ \pm 1,18}$ & 23,3 \\
\hline 4 & $6,43^{ \pm 0,20}$ & 14,1 & $33,22^{ \pm 2,36}$ & 31,7 & $11,31^{ \pm 0,67}$ & 26,5 & $17,70^{ \pm 0,62}$ & 15,7 & $6,55^{ \pm 0,20}$ & 13,9 & $29,08^{ \pm 2,24}$ & 34,4 \\
\hline$K_{4}$ & $7,39^{ \pm 0,28}$ & 17,1 & $26,20^{ \pm 1,51}$ & 25,8 & $24,55^{ \pm 0.91}$ & 16,6 & $10,05^{ \pm 0,59}$ & 26,2 & $8,60^{ \pm 0,35}$ & 18,0 & $22,10^{ \pm 1,40}$ & 28,4 \\
\hline 5 & $7,21^{ \pm 0,24}$ & 15,1 & $27,85^{ \pm 2,16}$ & 34,7 & $16,48^{ \pm 0,94}$ & 25,4 & $13,85^{ \pm 0,78}$ & 25,1 & $8,62^{ \pm 0,22}$ & 11,3 & $21,43^{ \pm 0,96}$ & 20,1 \\
\hline$K_{5}$ & $7,19^{ \pm 0,29}$ & 17,9 & $28,92^{ \pm 1,87}$ & 28,9 & $16,06^{ \pm 1,04}$ & 27,8 & $14,50^{ \pm 0,84}$ & 26,0 & $8,94^{ \pm 0,27}$ & 13,8 & $20,50^{ \pm 0,59}$ & 12,8 \\
\hline 6 & & & & & $13,70^{ \pm 0,97}$ & 31,5 & $16,77^{ \pm 1,11}$ & 29,6 & & & & \\
\hline$K_{6}$ & & & & & $12,85^{ \pm 0,78}$ & 27,1 & $16,63^{ \pm 1,19}$ & 32,1 & & & & \\
\hline
\end{tabular}

У червні-липні (період активної вегетації), на фоні загального зростання показників поляризаційної ємності та зниження імпедансу, відчутно зросли коефіцієнти варіації поляризаційної ємності на ПП $\left(\left(F_{\text {факт }}=47,56\right.\right.$ $\left.\left.>F_{0,95}(1 ; 21)=4,35\right)\right)$ порівняно 3 попереднім періодом, тоді як для імпедансу таке збільшення коефіцієнта варіації не спостерігається $\left(\left(F_{\text {факт }}=0,24<F_{0,95}\right.\right.$ $(1 ; 21)=4,35))$. Загалом за величиною поляризаційної ємності дослідні насадження Pinus sylvestris (окрім ПП №3 та ПП №4) не істотно відрізнялися від контрольних. Їх показники становили 89,3-97,5 \% до дослідних $\quad\left(t_{\phi}=0,31-1,46 ; \quad t_{05}=2,02\right)$. Поляризаційна ємність на дослідних ПП №1-ПП №2 та ПП №5ПП №6 коливалася у межах $13,70^{ \pm 0,97}-20,05^{ \pm 1,15} \mathrm{nF}$, а на контрольних вона становила $12,85^{ \pm 0,78}-17,90^{ \pm 0,91} \mathrm{nF}$. Значення імпедансу у період активної вегетації на цих же ПП змінювалося у межах $10,55^{ \pm 0,73}-16,77^{ \pm 1,11}$ кОм на дослідних і $10,20^{ \pm 0,54}-16,63^{ \pm 1,19}$ кОм - на контрольних. Показники становили 96,7-112,8\% до дослідних $\left(t_{\phi}=0,09-1,34 ; t_{05}=2,02\right)$. Діелектричні показники у червні-липні достовірно відрізнялися від контрольних на ПП №3 $\left(C-t_{\phi}=2,72\right.$ та $\left.R-t_{\phi}=3,05 ; t_{05}=2,02\right)$ та дуже істотно на ПП №4: $\left(C-t_{\phi}=11,69\right.$ та $R-t_{\phi}=8,93$; $\left.t_{05}=2,02\right)$.

Дослідження, здійснені у жовтні-листопаді, вказують на поступове зниження інтенсивності фізіологічних процесів у Pinus sylvestris порівняно з літнім періодом, про що свідчать встановлені нами діелектричні показники. На цьому тлі відчутно знизилися коефіцієнти варіації поляризаційної ємності на пробних площах $\left(\left(F_{\text {факт }}=30,58 \gg F_{0,95}(1 ; 21)=4,35\right)\right)$ порівняно 3 попереднім періодом, водночас коефіцієнти варіації показників імпедансу залишилися на попередньому рівні $\left(\left(F_{\text {факт }}=0,08<F_{0,95}(1 ; 21)=4,35\right)\right)$. У період переходу до стану спокою (жовтень-листопад) поляризаційна ємність на дослідних ПП №1-ПП №5 коливалася у межах $6,03^{ \pm 0,29}-8,62^{ \pm 0,22} \mathrm{nF}$, водночас на контрольних ПП №K - -ПП №K 5 вона становила $6,48^{ \pm 0,23}-9,23^{ \pm 0,38} \mathrm{nF}$ (див. табл. 4). Коефіцієнт варіації показника незначний як на дослідних (8,9-21,7 \%), так і на контрольних $(13,8$ $21,0 \%$ ) пробних площах. Достовірність різниці між дослідними і контрольними показниками була зафіксована як і в попередні періоди на ПП №3 (ДП "Баранівське ЛМГ") та ПП №4 (ДП "Лугинське ЛГ") (відповідно $t_{\phi}=3,88$ та $t_{\phi}=5,08$ при $t_{05}=2,02$ ), де показники поляризаційної ємності на контрольних ділянках були вищими на 27,3-31,9\% (див. табл. 5). Для інших пар ПП не існує достовірної $\left(t_{\phi}=0,93-1,50 ; t_{05}=2,02\right)$ різни- ці. У жовтні-листопаді імпеданс на ПП №1-ПП №5 коливався у межах $21,43^{ \pm 0,96}-33,05^{ \pm 2,39}$ кОм, а на ПП №К ${ }_{1}^{-}$ ПП №K 5 він становив 20,45 $5^{ \pm 1,05}-33,35^{ \pm 2,49}$ кОм. Коефіцієнт варіації на дослідних ПП становить 20,1-38,4 \%, а на контрольних - 12,8-33,4 \%. Достовірність різниці показників імпедансу зафіксовано для ПП №3 та ПП №4 (відповідно $t_{\phi}=2,60$ та $t_{\phi}=2,64$ при $t_{05}=2,02$ ) порівняно 3 контрольними показниками. На інших ПП контрольні показники становлять 95,6-104,1 \% до дослідних $\left(t_{\phi}=0,09-0,82 ; t_{05}=2,02\right)$

Табл. 5. Достовірність різниці ( $t$-критерій Ст'юдента) між величинами діелектричних показників Pinus sylvestris

у деревостанах на території вольєрів та за їх межами (контроль)

\begin{tabular}{|c|c|c|c|c|}
\hline \multirow{2}{*}{$№$} & Поляризаційна ємність, $(C)$ & \multicolumn{2}{c|}{ Імпеданс, $(R)$} \\
\cline { 2 - 5 } п/п & $t_{\phi}$ & $\%$ & $t_{\phi}$ & $\%$ \\
\hline \multicolumn{5}{|c|}{ Період виходу зі стану спокою } \\
\hline 1 & 0,73 & 96,2 & 0,46 & 96,4 \\
\hline 2 & 0,03 & 100,1 & 0,80 & 95,2 \\
\hline 3 & 2,81 & 115,0 & 2,24 & 81,9 \\
\hline 4 & 2,78 & 114,9 & 2,51 & 78,9 \\
\hline 5 & 0,05 & 99,7 & 0,38 & 103,8 \\
\hline \multicolumn{5}{|c|}{ Період активної вегетаиї̈ } \\
\hline 1 & 0,32 & 97,4 & 1,34 & 112,8 \\
\hline 2 & 1,46 & 89,3 & 0,38 & 96,7 \\
\hline 3 & 2,72 & 125,5 & 3,05 & 74,0 \\
\hline 4 & 11,69 & 217,1 & 8,93 & 56,8 \\
\hline 5 & 0,31 & 97,5 & 0,57 & 104,7 \\
\hline 6 & 0,69 & 93,8 & 0,09 & 99,2 \\
\hline \multicolumn{5}{|c|}{ Період переходу до стану спокоюо } \\
\hline 1 & 1,25 & 107,5 & 0,09 & 104,1 \\
\hline 2 & 1,50 & 107,2 & 0,66 & 95,6 \\
\hline 3 & 3,88 & 127,3 & 2,60 & 75,4 \\
\hline 4 & 5,08 & 131,9 & 2,64 & 76,0 \\
\hline 5 & 0,93 & 103,7 & 0,82 & 95,7 \\
\hline
\end{tabular}

Примітка: табличне значення $t$-критерію Ст'юдента $\left(t_{05}\right)$ дорівнює 2,02 .

Ми встановили, що вольєри ТОВ "УТМР" та ДП "Баранівське ЛМГ" створені майже одночасно, а досліджувані насадження Pinus sylvestris одного віку, проте у першому вольєрі не виявлено відмінностей між діелектричними показниками дослідних i контрольних ПП. Натомість у вольєрі ДП "Баранівське ЛМГ" напіввільне утримання спочатку Cervus nippon, а згодом Sus scrofa вплинуло на інтенсивність процесів життєдіяльності у Pinus sylvestris. Можливо зростаючи в умовах свіжого дубово-соснового субору $\left(\mathrm{B}_{2}-\right.$-дС) дерева $\mathrm{Pi}$ nus sylvestris стають більш вразливими до впливу мисливської фауни, ніж за умов вологого грабово-дубово- 
соснового сугруду $\left(\mathrm{C}_{3}\right.$-гдС). Пробні площі у вольєрах ГО "ЖОМК "Касадор" та ДП "Лугинське ЛГ" розташовані у свіжому грабово-дубово-сосновому сугруді $\left(\mathrm{C}_{2}-\right.$ гдС). Тривалість експлуатації першого 3 цих вольєрів на 10 років більша, проте саме тут показники поляризаційної ємності та імпедансу не відрізняються від контрольних. Відзначимо, що у вольєрі ДП "Лугинське ЛГ" у період активної вегетації ми зафіксували найбільшу різницю між діелектричними показниками на дослідній та контрольній пробних площах (C$t_{\phi}=11,69$ та $\left.R-t_{\phi}=8,93 ; t_{05}=2,02\right)$.

Експлуатація вольєра ДП "Коростишівське ЛГ" тривала упродовж 2012-2017 рр. Максимальна чисельність тварин з урахуванням молодняка становила 15 особин. Дослідження, здійснені у 2019 р., не виявили відхилення у показниках поляризаційної ємності та імпедансу насаджень Pinus sylvestris, що зростають у вольєрі та поза ним. Це узгоджується з результатами наших попередніх досліджень в умовах вольєрів МСК "Сокіл" (Західне Полісся) [14]. Встановлено, що за умови слабкого впливу Sus scrofa на лісові біоценози достовірної різниці між діелектричними показниками дослідних i контрольних насаджень Pinus sylvestris немає. Натомість хоч і не тривала, проте інтенсивна експлуатація вольєрів неодмінно призводить до погіршення життєвого стану соснових насаджень [13]. Подібна реакція дерев Pinus sylvestris стається під тиском інших біотичних чинників. Так, дослідження, здійснили В. К. Заїка та Ю. Л. Рибак [26], вказують, що дерева Pinus sylvestris середнього ступеня ураження шютте звичайним (Lophodermium pinastri (Schrad.) Chévall) за величиною діелектричних показників не відрізняються від здорових дерев. Істотне зменшення показників поляризаційної ємності та зростання показників імпедансу, а також порушення характеру метаболічних перетворень, виявлено у дерев сильного ступеня ураження Lophodermium pinastri. Подібна картина спостерігається в разі ураження сосновим вертуном (Melampsora pinitorqua (Br.) Rostr) [25] та опеньком осіннім (Armillariella mellea (Fr. ex Vahl.) Karst.) [3].

\section{Висновки}

Сезонна зміна діелектричних показників дослідних і контрольних насаджень Pinus sylvestris у вольєрах ТОВ "УТМР", ГО "ЖОМК "Касадор", ДП "Баранівське ЛМГ", ДП "Лугинське ЛГ", ДП "Коростишівське ЛГ" свідчить про неоднозначність впливу напіввільного утримання Sus scrofa на життєдіяльність дерев.

Згідно з результатами наших досліджень, чіткої залежності між тривалістю експлуатації вольєрів та діелектричними показниками Pinus sylvestris не встановлено, проте можна говорити про деякі закономірності, які потребують всебічного та досконалого аналізу.

Можна констатувати, що нетривала та помірна за інтенсивністю експлуатація вольєрів у перспективі не несе видимих негативних наслідків для процесів життєдіяльності пристигаючих і стиглих насаджень Pinus sylvestris в умовах свіжого $\left(\mathrm{C}_{2}\right.$-гдС) та вологого $\left(\mathrm{C}_{3-}\right.$ гдС) грабово-дубово-соснового сугруду.

Також з огляду на отримані результати цілком ймовірно припустити, що ступінь впливу напіввільного утримання Sus scrofa на життєздатність дерев Pinus sylvestris залежить від віку та складу деревостану, типу лісорослинних умов.

\section{References}

1. Chemerys, I. A. (2008). Phytoindication of the state of the environment using electrophysiological methods. Reports of the National Academy of Sciences of Ukraine, 2, 186-191. [In Ukrainian].

2. Derekh, O. I. (2014). Dielectric parameters of Oak and Beech trees of areas with different stages of recreational digression in green space of Lviv. Scientific Bulletin of UNFU, 24(8), 119-124. [In Ukrainian].

3. Derevjanchuk, Yu. L., \& Zaika, V. K. (2011). The morphophysiological reaction of pine trees infecting by Armillariella mellea. Scientific Bulletin of UNFU, 21(9), 18-24. [In Ukrainian].

4. Fensom, D. S. (1963). The bioelectrical potentials of plants and their functional significance. Can. J. Bot., 41, 831-851.

5. Fensom, D. S. (1966). On measuring electrical resistance in situ in higher plants. Can. L. Plant Sci., 46, 169-175.

6. Hayden, R. I., Moyse, C. A., Calder, F. W., Crawford, D. P., \& Fensom, D. S. (1969). Electrical Impedance Studies on Potato and Alfalfa Tissue. Journal of Experimental Botany, Vol. 20, Issue 2, May 1969, 177-200.

7. Humeniuk, I. R., Zaika, V. K., \& Bondarenko, V. D. (2012). Stan hraba zvychainoho v lisostanakh zapovidnyka "Medobory". (Part 1). Naukovyi visnyk Natsionalnoho universytetu bioresursiv $i$ pryrodokorystuvannia Ukrainy: Seriia Lisivnytstvo ta dekoratyvne sadivnytstvo, 171, 57-60. [In Ukrainian].

8. Karasev, V. N., \& Karaseva, M. A. (2016). Diagnostics of species viability on coniferous plantations based on bioelectric indicators. Vestnik of Volga State University of Technology. Ser.: Forest. Ecology. Nature Management, 2(30), 24-35. https://doi.org/10.15350/2306-2827.2016.2.24

9. Karasev, V. N., \& Karaseva, M. A. (2004). Ecological-and-physiological diagnostics of coniferous trees viability. Forestry Journal, 4, 28-33. [In Russian].

10. Karasev, V. N., Karaseva, M. A., Serebryakova, N. E., \& Lazareva, S. M. (2014). Ecological and physiological assessment of adaptation of the introduced plants (coniferous trees) in the Middle Volga region. Vestnik of Volga State University of Technology. Ser.: Forest. Ecology. Nature Management, 4(24), 55-66. [In Russian].

11. Karpyn, N. I, \& Zayika, V. K. (2017). Dielectric indexes of Tilia cordata Mill. and Tilia platyphyllos Scop. in various conditions of Lviv City. Scientific Bulletin of UNFU, 27(1), 33-37. https://doi.org/10.15421/40270107

12. Kerimov, E. I., \& Zaika, V. K. (2018). Dielectric properties of tree species in stands containing european larch. Scientific Bulletin of UNFU, 28(8), 23-27. https://doi.org/10.15421/40280804

13. Kratiuk, O. L. (2019). Seasonal changes in dielectric parameters of Scots pine in semi-free hunting animals keeping. Ecological Sciences, 4(27), 192-196. https://doi. org/10.32846/23069716-2019-4-27-29

14. Kratiuk, O. L. (2019). Seasonal changes in dielectric parameters of scots pine in semi-free Wild boars keeping on the territory of Hunting-sports club "Sokil". Ecological Sciences, 1(28), 257-262. https://doi. org/10. 32846/2306-9716/2020. eco. 1-28. 40

15. Kratiuk, O. L., \& Kratyuk, V. L., (2019). Plant electrophysiology trends in forestry research. Topical issues of methods of teaching natural sciences: International scientific and practical conference. Lublin, Republic of Poland: Baltija Publishing.

16. Krynytskyi, H. T. (1992). Pro metodyku vykorystannia elektrofiziolohichnykh pokaznykiv dlia vyznachennia zhyttiezdatnosti derevnykh roslyn. Forestry, Forest, Paper and Woodworking Industry, 23, 3-10. [In Ukrainian].

17. Krynytskyi, H. T., \& Halushka, V. P. (2005). Electro-physiology reaction of Scots pine-tree on taping of resin. Scientific Bulletin of USUFWT, 15(2), 8-13. [In Ukrainian].

18. Krynytskyi, H. T., \& Skolskyi, I. M. (2015). Use of dielectric parameters for determination of wych-elm (mountain) trees vitality. Proceedings of the Forestry Academy of Sciences of Ukraine, 13, 83-88. [In Ukrainian]. 
19. Krynytskyi, H. T., \& Zaika, V. K. (2004). Elektrofiziolohichna reaktsiia kultur sosny zvychainoi na vysoki rivni khronichnoho radiatsiinoho oprominennia. Status and trends of development of forestry education, science and forestry in Ukraine, 14(5), 8-14. [In Ukrainian].

20. Krynytskyi, N. T. (1990). Bioelektricheskii metod opredeleniia zhiznesposobnosti drevesnykh rastenii na nachalnykh etapakh ontogeneza. Scientific and Production Association of Space Research, 85, 61-68. [In Russian].

21. Krynytskyi, N. T. (2001). Elektrofiziolohichni doslidzhennia derevnykh roslyn v Ukraini. Fiziolohiia roslyn v Ukraini na mezhi tysiacholit. 2, 223-237. [In Ukrainian].

22. Mac Dougall, R., Maclean, D. A., \& Thompson, $R$. G. (1988). The use of electrical capacitance to determine growth and vigor of spruce and fir trees and stands in New Brunswicch. Can. J. Forest Res., 5, 587-594.

23. Mac Dougall, R., Thompson, R. G., \& Harald, Piene. (1987). Stem electrical capacitance and resistance measurements as related to total foliar biomass of balsam fir trees. Can. J. Forest Res., 17(9), 1070-1074.

24. Matorkin, A. A., \& Karaseva, M. A. (2007). Information capacity of the impedance of pre-cambial tissue complex in coniferous species when evaluating their viability. Contemporary physiology of plants: from molecules to ecosystems: proceedings of presentations from the International conference, 2, 265-266. [In Russian].

25. Rybak, Yu. L. (2012). The electrophysiological indices of Scots pine infected by the Melampsora pinitorqua in Western Polesie. Scientific Bulletin of UNFU, 22(12), 42-48. [In Ukrainian].

26. Rybak, Yu. L., \& Zaika, V. K. (2013). Changes in the electrophysiological activity of Scots pine trees infected by the
Lophodermium pinastri. Scientific Bulletin of UNFU, 23(2), 9096. [In Ukrainian].

27. Shigo, Alex, L., \& Shortle, Walter, C. (1985). Spruce Budworms Handbook. Shigometry - a reference guide. United State Department of Agriculture, Forest Service, 48. Retrieved from: https://www.fs.fed.us/nrs/pubs/ag-handbook/ah646.pdf

28. Shortle, W. C. (2001). Shigometer. Encyclopedia of plant pathology, 2, Set, John Wiley and Sons, Inc., 902-903.

29. Skutt, Richard, H., Shigo, Alex, L., \& Lessard, Ronald, A. (1972). Detection of Discolored and Decayed Wood in Living Trees Using a Pulsed Electric Current. Canadian Journal of Forest Research, 2(1), 54-56.

30. Tkach, V. P., Los, S. A., Tereshchenko, L. I., Torosova, L. O., Vysotska, N. Ju., \& Volosyanchuk, R. T. (2013). Suchasnyi stan i perspektyvy rozvytku lisovoi selektsii v Ukraini [Present state and prospects for development of forest breeding in Ukrainian]. Forestry and Forest Melioration, 123, 3-12. [In Ukrainian].

31. Zaika, V. K. (2004). Dielectric parameters of a Pinus sylvestris L. on polluted with radiation territories. Scientific Bulletin of USUFWT, 14(1), 12-15. [In Ukrainian].

32. Zaika, V. K., \& Rudenko, A. V. (2012). Morpho-physiological characteristics of Scots Pine in the pine forest of Small Polissya. Scientific Bulletin of UNFU, 22(9), 9-13. [In Ukrainian].

33. Zaika, V. K., \& Rudenko, A. V. (2019). Morphological and functional features of Scots pine in pine forest stands of the Small Polissia. Proceedings of the Forestry Academy of Sciences of Ukraine, 19, 11-21. https://doi.org/10.15421/411923

O. L. Kratiuk

Zhytomyr National Agroecological University, Zhytomyr, Ukraine

\section{CHANGING OF THE DIELECTRIC PARAMETERS OF SCOTS PINE IN THE CONDITIONS OF SEMI-FREE MAINTENANCE OF WILD BOAR}

The example of Central Polissya of Ukraine shows the peculiarities of the use of electrophysiological indicators is a promising method of indicating the stages of the impact of semi-free keeping of hunting animals on forest plantations. The basic principles of balanced forestry and hunting management require a profound understanding of the processes of interaction of game animals with forest stands. The use of electrophysiological indicators is a promising method of indicating the stages of influence of semi-free maintenance of game animals. In the course of research we investigated the seasonal changes of dielectric parameters of Scotch pine $(P i$ nus sylvestris L.) on the territory of the enclosures with the area up to 5.0 ha that are used by UTMR LLC, Kasador Zhytomyr Regional Hunting Club NGO, Baranivske Hunting Forestry SOE, Lugynske Forestry SOE, Korostyshivske Forestry SOE, and IrbisBrachky Romanivsky HRS NGO. Twelve trial plots were laid, (where 6 of them were control ones) in pine stands aged 60-91 years growing according to $\mathrm{I}^{\mathrm{B}}$-II classes of stand productivity. Trial plots were located within four forest types such as $\mathrm{B}_{2}-д \mathrm{C}, \mathrm{C}_{2}-г д \mathrm{C}$, and $\mathrm{C}_{3}$-гдС. The dielectric parameters were measured in February - March, June - July, and October - November during the period of 2018-2020 with F4320 analogue device at frequency of $1 \mathrm{kHz}$ according to the method by G.T. Krynytsky. Dielectric indicators are revealed to characterize seasonal changes in the intensity of life processes. The general tendency is observed in the gradual decrease of the impedance value and the increase of the polarization capacity during the transition of the trees from dormancy to vegetation and vice versa - the increase of the impedance and the decrease of the polarization capacity during the reverse processes. The polarization capacity in the trial plots was found to fluctuate in February - March ranging $5.68^{ \pm 0,17}-7.46^{ \pm 0,25} \mathrm{nF}$ (significance of the difference with the control values $t_{f}=0.08-0.73 ; t_{05}=2.02$ ), in June - July it increased to $11.31^{ \pm 0,67}-24.55^{ \pm 0.91} \mathrm{nF}$, and in October - November it decreased to $6.03^{ \pm 0,29}-8.97^{ \pm 0,27} \mathrm{nF}$. Firstly, impedance during the season initially decreased from $22.43^{ \pm 0,63}$ $36.10^{ \pm 2,48} \mathrm{kOhm}$ to $10.20^{ \pm 0,54}-21.83^{ \pm 1,35} \mathrm{kOhm}$, but then it increased to $20.50^{ \pm 0,59}-33.35^{ \pm 2,49} \mathrm{kOhm}$. As a result of research, we have found a significant difference between the dielectric values of pine stands in Baranivske Hunting Forestry SOE $\left(C-t_{f}=2.72-3.88\right.$ and $\left.R-t_{f}=2.24-3.05 ; t_{05}=2.02\right)$ and Lugynske Forestry SOE $\left(C-t_{f}=2.78-11.69\right.$ and $\left.R-t_{f}=2.52-8.93 ; t_{05}=2.02\right)$. The polarization capacity coefficient in the trial plots according to the periods of observation was found to be 14.1-19.4\%, 16.6-31.5\%, and 8.9-21.7\%, and impedance $-12.7-34.7 \%, 15.7-35.2 \%$, and 12.8-38.4\% respectively. The enclosures of UTMR LLC and Baranivske Hunting Forestry SOE with an exploitation period of 36 and 34 years, respectively, and Pinus sylvestris trial plots are revealed to be of the same age, although we found no differences between the dielectric parameters of the trial and control plantations in the first enclosure. In return, semi-free maintenance of game animals of Cervus nippon, and then Sus scrofa in Baranivske Hunting Forestry SOE had a visible effect on the vitality of Pinus sylvestris trees. The exploitation period of the enclosure in Kasador Zhytomyr Regional Hunting Club NGO was 10 years longer than in Lugynske Forestry SOE, but here the coefficients of polarization capacity and the impedance do not differ from the control ones. Short-term and moderate-intensity exploitation of enclosures in the future is supposed to have little visible negative consequences for the vitality of ripening and mature Pinus sylvestris stands.

Keywords: polarization capacity; impedance; Pinus sylvestris L.; enclosure; game fauna. 